\title{
Quantitative Estimation of the Hydrogen-Atom-Donating Ability of 4-Substituted Hantzsch Ester Radical Cations
}

\author{
Guang-Bin Shen, Li Xie, Yun-Xia Wang, Teng-Yang Gong, Bin-Yu Wang, Yu-He Hu, Yan-Hua Fu, \\ and Maocai Yan*
}

Cite This: ACS Omega 2021, 6, 23621-23629

Read Online

\begin{tabular}{|c|c|}
\hline $\mathrm{R}^{\bullet}$ or $\mathrm{H}^{\circ}$ donors? & $\underbrace{\mathrm{OHH}}_{\mathrm{OH}}$ \\
\hline $\begin{array}{cc}\Delta G^{\circ}{ }_{\mathrm{HD}}\left(\mathrm{XRH}^{+}\right) & 19.35 \sim 31.25 \mathrm{kcal} / \mathrm{mol} \\
\Delta G_{\mathrm{HD}}^{\ddagger}\left(\mathrm{XRH}^{+}\right) & 29.81 \sim 39.00 \mathrm{kcal} / \mathrm{mol}\end{array}$ & $\begin{array}{cc}\Delta G^{\circ}{ }_{\mathrm{HD}}\left(\mathrm{NADH}^{+}\right) & 23.90 \mathrm{kcal} / \mathrm{mol} \\
\Delta G_{\mathrm{HD}}^{\ddagger}\left(\mathrm{NADH}^{+}\right) & 31.25 \mathrm{kcal} / \mathrm{mol}\end{array}$ \\
\hline
\end{tabular}

ABSTRACT: The purpose of this study is to investigate thermodynamic and kinetic properties on the hydrogen-atom-donating ability of 4-substituted Hantzsch ester radical cations $\left(\mathrm{XRH}^{\bullet+}\right)$, which are excellent NADH coenzyme models. Gibbs free energy changes and activation free energies of $17 \mathrm{XRH}^{\bullet+}$ releasing $\mathrm{H}^{\bullet}$ [denoted as $\Delta G_{\mathrm{HD}}^{\mathrm{o}}\left(\mathrm{XRH}^{\bullet+}\right)$ and $\left.\Delta G_{\mathrm{HD}}^{\neq}\left(\mathrm{XRH}^{\bullet+}\right)\right]$ were calculated using density functional theory (DFT) and compared with that of Hantzsch ester $\left(\mathrm{HEH}_{2}\right)$ and NADH. $\Delta G_{\mathrm{HD}}^{\mathrm{o}}\left(\mathrm{XRH}^{\bullet+}\right)$ range from 19.35 to $31.25 \mathrm{kcal} / \mathrm{mol}$, significantly lower than that of common antioxidants (such as ascorbic acid, BHT, the NADH coenzyme, and so forth). $\Delta G_{\mathrm{HD}}^{\neq}\left(\mathrm{XRH}^{\bullet+}\right)$ range from 29.81 to $39.00 \mathrm{kcal} / \mathrm{mol}$, indicating that $\mathrm{XRH}^{\bullet+}$ spontaneously releasing $\mathrm{H}^{\bullet}$ are extremely slow unless catalysts or active intermediate radicals exist. According to the computed data, it can be inferred that the Gibbs free

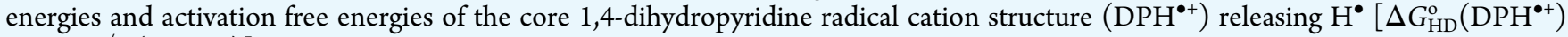
and $\left.\Delta G_{\mathrm{HD}}^{\neq}\left(\mathrm{DPH}^{\bullet+}\right)\right]$ should be $19-32 \mathrm{kcal} / \mathrm{mol}$ and $29-39 \mathrm{kcal} / \mathrm{mol}$ in acetonitrile, respectively. The correlations between the thermodynamic driving force $\left[\Delta G_{\mathrm{HD}}^{\mathrm{o}}\left(\mathrm{XRH}^{\bullet+}\right)\right]$ and the activation free energy $\left[\Delta G_{\mathrm{HD}}^{\neq}\left(\mathrm{XRH}^{\bullet+}\right)\right]$ are also explored. Gibbs free energy is the important and decisive parameter, and $\Delta G_{\mathrm{HD}}^{\neq}\left(\mathrm{XRH}^{\bullet+}\right)$ increases in company with the increase of $\Delta G_{\mathrm{HD}}^{\mathrm{o}}\left(\mathrm{XRH}^{\bullet+}\right)$, but no simple linear correlations are found. Even though all $\mathrm{XRH}^{\bullet+}$ are judged as excellent antioxidants from the thermodynamic view, the computed data indicate that whether $\mathrm{XRH}^{\bullet+}$ is an excellent antioxidant in reaction is decided by the $\mathrm{R}$ substituents in 4-position. $\mathrm{XRH}^{\bullet+}$ with nonaromatic substituents tend to release $\mathrm{R}^{\bullet}$ instead of $\mathrm{H}^{\bullet}$ to quench radicals. $\mathrm{XRH}^{\bullet+}$ with aromatic substituents tend to release $\mathrm{H}^{\bullet}$ and be used as antioxidants, but not all aromatic substituted Hantzsch esters are excellent antioxidants.

\section{INTRODUCTION}

4-Substituted Hantzsch esters (XRH, Scheme 1), known as dipine drugs, are used to treat hypertensive and cardiovascular diseases as calcium channel modulators, ${ }^{1,2}$ which also have the 1,4-dihydropyridine structure and used as excellent $\mathrm{NADH}$ coenzyme models. ${ }^{3-5} \mathrm{XRH}$ were investigated as antioxidants to quench active radicals $\left(\mathrm{R}^{\bullet}, \mathrm{RO}^{\bullet}, \mathrm{ROO}^{\bullet}, \mathrm{RS}^{\bullet}\right.$ or $\mathrm{RNH}^{\bullet}$, and so on) in vivo and vitro in many papers. ${ }^{6-9}$ In recent years, $\mathrm{XRH}$ have been examined as alkyl reagents to synthetize various bioactive molecules, and the key elementary step is $\mathrm{XRH}^{\bullet+}$ releasing $\mathrm{R}^{\bullet}\left(\mathrm{XRH}^{\bullet+} \rightarrow \mathrm{XH}^{+}+\mathrm{R}^{\bullet}\right) \cdot{ }^{10-16}$ However, not all $\mathrm{XRH}^{\bullet+}$ can release $\mathrm{R}^{\bullet}$; for example, 4-phenyl-Hantzsch ester could not release $\mathrm{Ph}^{\bullet}$ itself. ${ }^{10}$ We wonder that could $\mathrm{XRH}^{\bullet+}$ be used as $\mathrm{H}^{\bullet}$ donors served as radical scavengers just like $\mathrm{NADH}$ and $\mathrm{NADH}^{\bullet+}$ (Scheme 2). How could we quantitatively measure the hydrogen-atom-donating ability of $\mathrm{XRH}^{\bullet+}$ ? Since the key elementary step of $\mathrm{XRH}^{\bullet+}$ used as an antioxidant is
$\mathrm{XRH}^{\bullet+}$ releasing $\mathrm{H}^{\bullet}$, in this work, the characteristic physical parameters of $\mathrm{XRH}^{\bullet+}$, Gibbs free energy change $\left[\Delta G_{\mathrm{HD}}^{\mathrm{o}}\left(\mathrm{XRH}^{\bullet+}\right)\right]$ and activation free energy of $\mathrm{XRH}^{\bullet+}$ releasing $\mathrm{H}^{\bullet}\left[\Delta G_{\mathrm{HD}}^{\neq}\left(\mathrm{XRH}^{\bullet+}\right)\right]$, are obtained to judge the ability of $\mathrm{XRH}^{\bullet+}$ releasing $\mathrm{H}^{\bullet}$. However, because $\mathrm{XRH}^{\bullet+}$ is a kind of very active intermediate, $\Delta G_{\mathrm{HD}}^{\mathrm{o}}\left(\mathrm{XRH}^{\bullet+}\right)$ and $\Delta G_{\mathrm{HD}}^{\neq}\left(\mathrm{XRH}^{\bullet+}\right)$ on the process of $\mathrm{XRH}^{\bullet+}$ releasing $\mathrm{H}^{\bullet}$ are quite difficult to determine experimentally in labs. In present work, 17 important and well-designed XRH (Scheme 3) with

Received: July 21, 2021

Accepted: August 19, 2021

Published: September 2, 2021

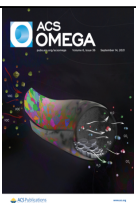


Scheme 1. Chemical Structures of XRH, $\mathrm{HEH}_{2}$ and $\mathrm{NADH}$<smiles>[R]C1C(C(=O)OCC)=C(C)NC(C)=C1C(=O)OCC</smiles>

XRH<smiles>CCOC(=O)C1=C(C)NC(C)=C(C(=O)OCC)C1</smiles>

$\mathrm{HEH}_{2}$

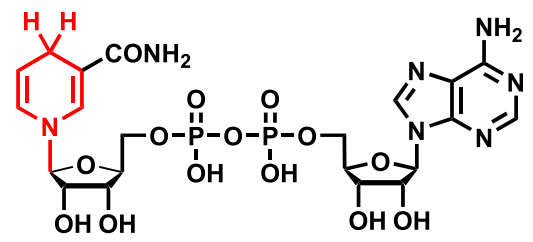

NADH

Scheme 2. Key Elementary Step of $\mathrm{XRH}^{\bullet+}$ Releasing $\mathrm{H}^{\bullet}$<smiles>[R]C1C(C(=O)OCC)=C(C)[NH+]([R17])C(C)=C1C(=O)OCC</smiles>

$\begin{array}{ll}\Delta H_{\mathrm{HD}}^{\circ}\left(\mathrm{XRH}^{+}\right)=? & \Delta G_{\mathrm{HD}}^{\circ}\left(\mathrm{XRH}^{+}\right)=? \\ \underset{\Delta H_{\mathrm{HD}}^{\ddagger}\left(\mathrm{XRH}^{+}\right)=?}{\Delta G_{\mathrm{HD}}^{\ddagger}\left(\mathrm{XRH}^{+}\right)=?}\end{array}$

(1)

\section{$+\mathrm{H}^{\circ}$}

Scheme 3. Chemical Structures of 17 XRH Investigated in This Work<smiles>C=CCC1C(C(=O)OCC)=C(C)NC(C)=C1C(=O)OCC</smiles><smiles>CCOC(=O)C1=C(C)NC(C)=C(C(=O)OCC)C1C</smiles>

7RH<smiles>CCOC(=O)C1=C(C)NC(C)=C(C(=O)OCC)C1C(OC)OC</smiles>

13RH<smiles>CCOC(=O)C1=C(C)NC(C)=C(C(=O)OCC)C1C(=O)c1ccccc1</smiles><smiles>CCOC(=O)C1=C(C)NC(C)=C(C(=O)OCC)C1C(C)(C)C</smiles>

8RH<smiles>CCOC(=O)C1=C(C)NC(C)=C(C(=O)OCC)C1c1ccc(N(C)C)cc1</smiles>

14RH<smiles>CCOC(=O)C1=C(C)NC(C)=C(C(=O)OCC)C1C(F)(F)F</smiles>

3RH<smiles>CCOC(=O)C1=C(C)NC(C)=C(C(=O)OCC)C1Cc1ccccc1</smiles>

9RH<smiles>CCOC(=O)C1=C(C)NC(C)=C(C(=O)OCC)C1c1ccc([N+](=O)[O-])cc1</smiles>

$15 \mathrm{RH}$<smiles>CCOC(=O)C1=C(C)NC(C)=C(C(=O)OCC)C1C1CCCCC1</smiles><smiles>CCOC(=O)C1=C(C)NC(C)=C(C(=O)OCC)C1C(C)Br</smiles>

10RH<smiles>CCOC(=O)C1=C(C)NC(C)=C(C(=O)OCC)C1c1ccccc1</smiles>

16RH<smiles>CCOC(=O)C1=C(C)NC(C)=C(C(=O)OCC)C1CC</smiles>

$5 \mathrm{RH}$<smiles>CCOC(=O)C1=C(C)NC(C)=C(C(=O)OCC)C1CNC(=O)c1ccccc1</smiles>

11RH<smiles>CCOC(=O)C1=C(C)NC(C)=C(C(=O)OCC)C1C(C)C</smiles>

$6 \mathrm{RH}$<smiles>CCOCC1C(C(=O)OCC)=C(C)NC(C)=C1C(=O)OCC</smiles>

12 RH various substituents in the 4-position, such as allyl, benzoyl, benzyl, and so on, are selected to further investigate the hydrogen-atom-donating ability of $\mathrm{XRH}^{\bullet+}$ using density functional theory (DFT). We believe that these data would be helpful in the understanding and application of $\mathrm{XRH}^{\bullet+}$ as antioxidants or radical donors.

\section{METHODS}

For the elementary step on each $\mathrm{XRH}^{\bullet+}$ releasing $\mathrm{H}^{\bullet}$, we found out the reactant, transition state (denoted as TS), and product structure through geometrical optimization; vibrational analysis showed that the reactants and products had no imaginary frequencies, and each transition state had only one imaginary frequency. Intrinsic reaction coordinate (IRC) was calculated for each transition state, and electron spin density analysis was applied on the IRC products and verified that the cleavage products were hydrogen radicals and not protons. Then, thermodynamic correction values of enthalpy and Gibbs free energy were calculated at $298.15 \mathrm{~K}$, which were added to the single-point energy to give the enthalpy and Gibbs free energy, respectively. The $\Delta G_{\mathrm{HD}}^{\mathrm{o}}\left(\mathrm{XRH}^{\bullet+}\right), \Delta G_{\mathrm{HD}}^{\neq}\left(\mathrm{XRH}^{\bullet+}\right)$, enthalpy change $\left[\Delta H_{\mathrm{HD}}^{\mathrm{o}}\left(\mathrm{XRH}^{\bullet+}\right)\right]$, and activation enthalpy change $\left[\Delta H_{\mathrm{HD}}^{ \pm}\left(\mathrm{XRH}^{\bullet+}\right)\right]$ were calculated as eqs $1-4$, respectively.

$$
\begin{aligned}
& \Delta G_{\mathrm{HD}}^{\mathrm{o}}\left(\mathrm{XRH}^{\bullet+}\right)=G\left(\mathrm{XR}^{+}\right)+G\left(\mathrm{H}^{\bullet}\right)-G\left(\mathrm{XRH}^{\bullet+}\right) \\
& \Delta G_{\mathrm{HD}}^{\neq}\left(\mathrm{XRH}^{\bullet+}\right)=G(\mathrm{TS})-G\left(\mathrm{XRH}^{\bullet+}\right) \\
& \Delta \mathrm{H}_{\mathrm{HD}}^{\mathrm{o}}\left(\mathrm{XRH}^{\bullet+}\right)=H\left(\mathrm{XR}^{+}\right)+H\left(\mathrm{H}^{\bullet}\right)-H\left(\mathrm{XRH}^{\bullet+}\right) \\
& \Delta H_{\mathrm{HD}}^{\neq}\left(\mathrm{XRH}^{\bullet+}\right)=H(\mathrm{TS})-H\left(\mathrm{XRH}^{\bullet+}\right)
\end{aligned}
$$

The computation level of the geometrical optimization, vibrational analysis, and IRC calculation was B3LYP/6$31 \mathrm{G}(\mathrm{d}, \mathrm{p}) ;{ }^{17,18}$ DFT-D3 empirical dispersion corrections (BJ damping) ${ }^{19}$ were applied, and the SMD solvent model ${ }^{20}$ of acetonitrile was used. DFT calculations were accomplished in Gaussian $09,^{21}$ and electron spin density analysis was done in Multiwfn 3.7. ${ }^{22}$ The accuracy of the calculation method has been verified in our previous work, ${ }^{16}$ and the calculation deviation is less than $2.0 \mathrm{kcal} / \mathrm{mol}$. 
Table 1. Gibbs Free Energy Change $\left[\Delta G_{\mathrm{HD}}^{\mathrm{o}}\left(\mathrm{XRH}^{\bullet+}\right)\right]$, Activation Free Energy $\left[\Delta G_{\mathrm{HD}}^{\neq}\left(\mathrm{XRH}^{\bullet+}\right)\right]$, Enthalpy Change $\left[\Delta H_{\mathrm{HD}}^{\mathrm{o}}\left(\mathrm{XRH}^{\bullet+}\right)\right]$, and Activation Enthalpy $\left[\Delta H_{\mathrm{HD}}^{\neq}\left(\mathrm{XRH}^{\bullet+}\right)\right]$ of $\mathrm{XRH}^{\bullet+}$ Releasing $\mathrm{H}^{\bullet}$ at $298.15 \mathrm{~K}$ in Acetonitrile (Unit: kcal/ mol)

\begin{tabular}{ccccc} 
XRH & $\Delta G_{\mathrm{HD}}^{\mathrm{o}}\left(\mathrm{XRH}^{\bullet+}\right)$ & $\Delta G_{\mathrm{HD}}^{ \pm}\left(\mathrm{XRH}^{\bullet+}\right)$ & $\Delta H_{\mathrm{HD}}^{\mathrm{o}}\left(\mathrm{XRH}^{\bullet+}\right)$ & $\Delta H_{\mathrm{HD}}^{ \pm}\left(\mathrm{XRH}^{\bullet+}\right)$ \\
$1 \mathrm{RH}$ & 22.13 & 32.70 & 30.22 & 33.15 \\
$2 \mathrm{RH}$ & 23.56 & 34.90 & 30.80 & 33.72 \\
$3 \mathrm{RH}$ & 26.03 & 34.13 & 33.56 & 32.79 \\
$4 \mathrm{RH}$ & 23.68 & 32.69 & 30.57 & 32.04 \\
$5 \mathrm{RH}$ & 20.73 & 31.83 & 28.45 & 33.40 \\
$6 \mathrm{RH}$ & 23.68 & 32.08 & 31.88 & 30.70 \\
$7 \mathrm{RH}$ & 21.08 & 29.81 & 28.33 & 39.44 \\
$8 \mathrm{RH}$ & 31.25 & 39.00 & 38.31 & 35.60 \\
$9 \mathrm{RH}$ & 23.00 & 35.23 & 30.54 & 32.58 \\
$10 \mathrm{RH}$ & 24.71 & 32.56 & 31.64 & 35.75 \\
$11 \mathrm{RH}$ & 27.22 & 35.63 & 34.10 & 32.78 \\
$12 \mathrm{RH}$ & 23.03 & 31.88 & 30.34 & 35.35 \\
$13 \mathrm{RH}$ & 25.64 & 34.59 & 32.98 & 36.50 \\
$14 \mathrm{RH}$ & 26.20 & 35.99 & 33.65 & 30.93 \\
$15 \mathrm{RH}$ & 21.57 & 32.06 & 27.85 & 29.99 \\
$16 \mathrm{RH}$ & 19.35 & 30.71 & 26.85 & 29.16 \\
$17 \mathrm{RH}$ & 19.96 & 30.14 & 26.08 & \\
\hline
\end{tabular}

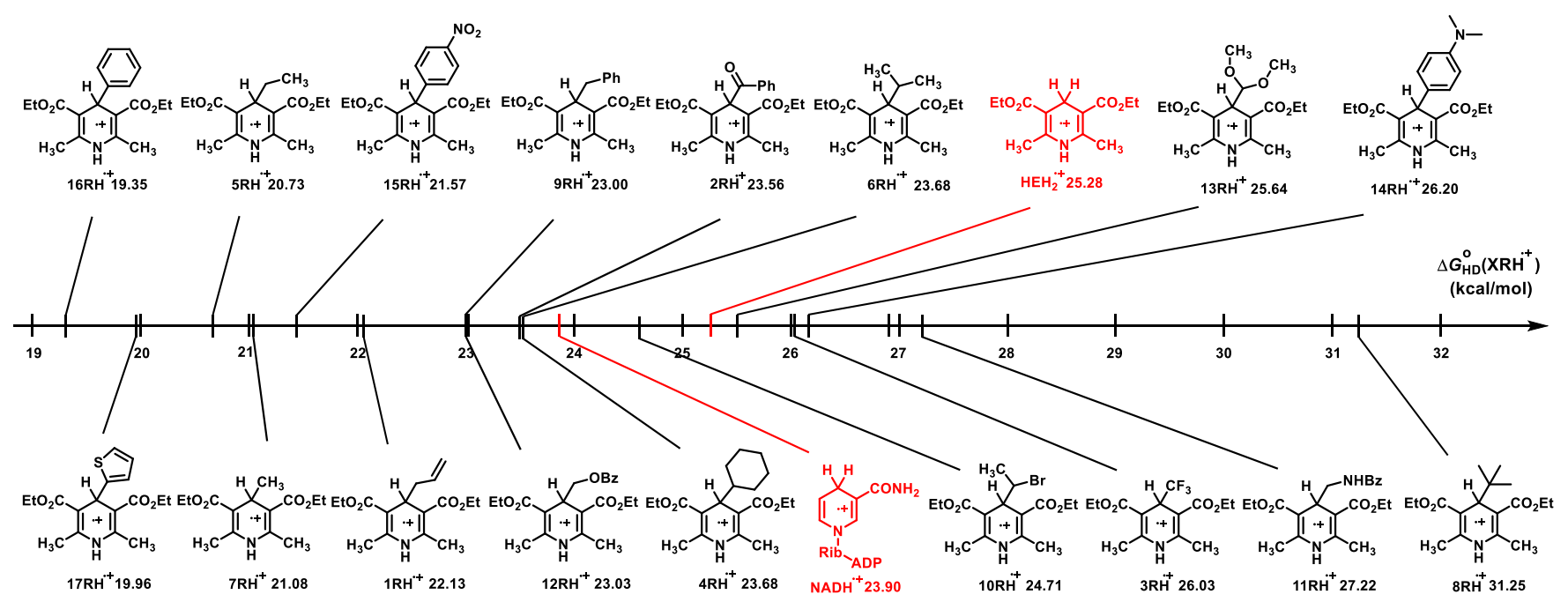

Figure 1. Comparison of structures and $\Delta G_{\mathrm{HD}}^{\mathrm{o}}\left(\mathrm{XRH}^{\bullet+}\right)$ values of the $17 \mathrm{XRH}$.

\section{RESULTS AND DISCUSSION}

The DFT-computed results of $\Delta G^{\mathrm{o}}\left(\mathrm{XRH}^{\bullet+}\right), \Delta G^{\neq}\left(\mathrm{XRH}^{\bullet+}\right)$, $\Delta H^{\circ}\left(\mathrm{XRH}^{\bullet+}\right)$, and $\Delta H^{\neq}\left(\mathrm{XRH}^{\bullet+}\right)$ of $17 \mathrm{XRH}^{\bullet+}$ releasing $\mathrm{H}^{\bullet}$ are listed in Table 1.

Gibbs Free Energy Change $\left[\Delta G_{\mathrm{HD}}^{\circ}\left(\mathrm{XRH}^{\bullet+}\right)\right]$. For clearance, structures and $\Delta G_{\mathrm{HD}}^{\mathrm{o}}\left(\mathrm{XRH}^{\bullet+}\right)$ values of $17 \mathrm{XRH}^{\bullet+}$ releasing $\mathrm{H}^{\bullet}$ are presented in Figure 1 . It is obvious that $\Delta G_{\mathrm{HD}}^{\mathrm{o}}\left(\mathrm{XRH}^{\bullet+}\right)$ of $\mathrm{XRH}^{\bullet+}$ releasing $\mathrm{H}^{\bullet}$ vary significantly, from $19.35\left(16 \mathrm{RH}^{\bullet+}\right)$ to $31.25 \mathrm{kcal} / \mathrm{mol}\left(8 \mathrm{RH}^{\bullet+}\right)$. All $17 \mathrm{XRH}^{\bullet+}$ have $\Delta G_{\mathrm{HD}}^{\mathrm{o}}\left(\mathrm{XRH}^{\bullet+}\right)$ values $\gg 0\left[\Delta G_{\mathrm{HD}}^{\mathrm{o}}\left(\mathrm{XRH}^{\bullet+}\right)>19.00\right.$ $\mathrm{kcal} / \mathrm{mol}]$, indicating that the process of $\mathrm{C}-\mathrm{H}$ bond cleavage from $\mathrm{XRH}^{\bullet+}$ is thermodynamically unfavorable and hence, the reaction of $\mathrm{XRH}^{\bullet+}$ releasing $\mathrm{H}^{\bullet}$ could not occur spontaneously at $298.15 \mathrm{~K}$ in acetonitrile. These results also show that substituents in the 4-position of $\mathrm{XRH}^{\bullet+}$ have large effects on the $\Delta G_{\mathrm{HD}}^{\mathrm{o}}\left(\mathrm{XRH}^{\bullet+}\right)$ values (varying by $11.9 \mathrm{kcal} / \mathrm{mol}$ ). We tried to divide the substituent effect into two different parts, that is, the steric effect as well as the electronic effect, and study the influence on the hydrogen-atom-donating ability of $\mathrm{XRH}^{\bullet+}$ but find no fundamental law or determining factor. For example, as for $7 \mathrm{RH}^{\bullet+}, 5 \mathrm{RH}^{\bullet+}, 6 \mathrm{RH}^{\bullet+}$, and $8 \mathrm{RH}^{\bullet+}$, the steric effect and electron-donating ability increase as the substituents change from $\mathrm{CH}_{3}-(7 \mathrm{RH})$, Et- $(5 \mathrm{RH})$, and $i \mathrm{Pr}-(6 \mathrm{RH})$ to $t \mathrm{Bu}-$ $(8 \mathrm{RH})$. However, the Gibbs free energy order is $\Delta G_{\mathrm{HD}}^{\mathrm{o}}\left(8 \mathrm{RH}^{\bullet+}\right)>\Delta G_{\mathrm{HD}}^{\mathrm{o}}\left(6 \mathrm{RH}^{\bullet+}\right)>\Delta G_{\mathrm{HD}}^{\mathrm{o}}\left(7 \mathrm{RH}^{\bullet+}\right)>$ $\Delta G_{\mathrm{HD}}^{\mathrm{o}}\left(5 \mathrm{RH}^{\bullet+}\right)$. In conclusion, no simple correlations between the 4-substituent properties and the $\Delta G_{\mathrm{HD}}^{\mathrm{o}}\left(\mathrm{XRH}^{\bullet+}\right)$ values are found, which indicate that the influence of 4-substituents' properties on the Gibbs free energy changes is rather complicated.

From Figure 1, it is found that the Gibbs free energy order is $\Delta G_{\mathrm{HD}}^{\mathrm{o}}\left(14 \mathrm{RH}^{\bullet+}\right)>\Delta G_{\mathrm{HD}}^{\mathrm{o}}\left(15 \mathrm{RH}^{\bullet+}\right)>\Delta G_{\mathrm{HD}}^{\mathrm{o}}\left(16 \mathrm{RH}^{\bullet+}\right)$ when the substituent changes from $4-\mathrm{NMe}_{2}-\mathrm{Ph}-$ and $4-\mathrm{NO}_{2}-\mathrm{Ph}-$ to $\mathrm{Ph}-$. The above phenomenon is not easily understandable, and intuitively, the $\Delta G_{\mathrm{HD}}^{\mathrm{o}}\left(16 \mathrm{RH}^{\bullet+}\right)$ value would be between the other two. We further analyze the intrinsic reason of the seemingly abnormal phenomenon. We find that $\Delta S_{\mathrm{HD}}^{\mathrm{o}}\left(14 \mathrm{RH}^{\bullet+}\right)$ and $\Delta S_{\mathrm{HD}}^{\mathrm{o}}\left(16 \mathrm{RH}^{\bullet+}\right)$ are almost the same (24.99 and $25.14 \mathrm{cal} \mathrm{mol}^{-1} \mathrm{~K}^{-1}$, respectively), but the $\Delta S_{\mathrm{HD}}^{\mathrm{o}}\left(15 \mathrm{RH}^{\bullet+}\right)\left(21.09 \mathrm{cal} \mathrm{mol}^{-1} \mathrm{~K}^{-1}\right)$ is quite lower than 


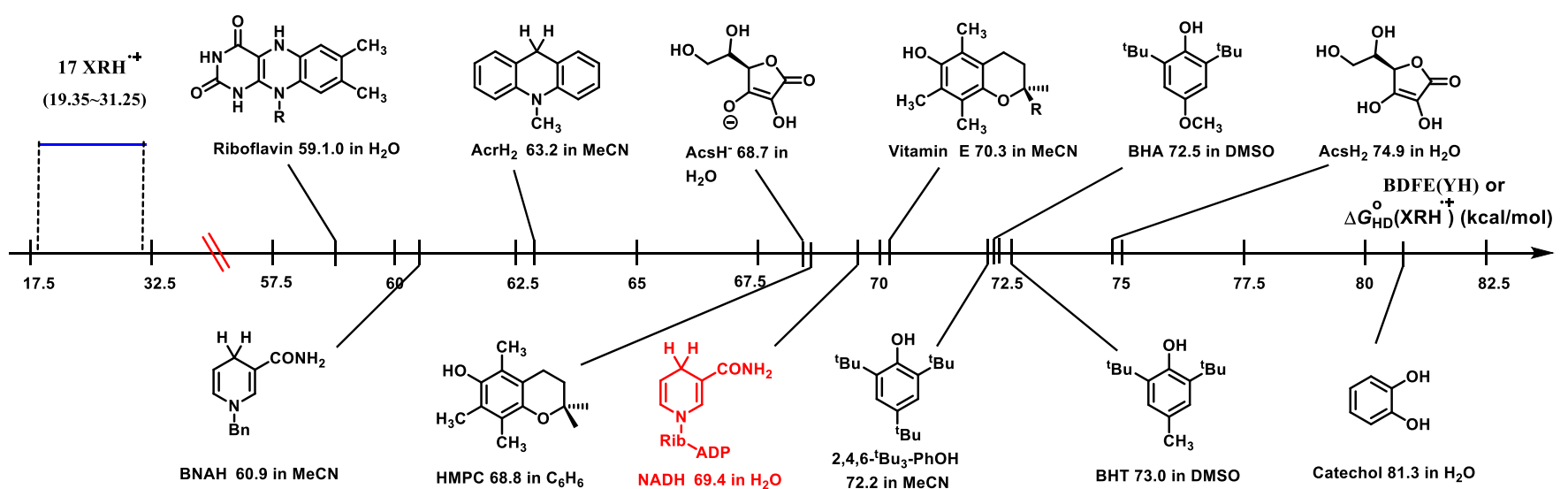

Figure 2. Comparison of $\Delta G_{\mathrm{HD}}^{\mathrm{o}}\left(\mathrm{XRH}^{\bullet+}\right)$ of $17 \mathrm{XRH}^{\bullet+}$ and $\Delta G_{\mathrm{HD}}^{\mathrm{o}}(\mathrm{YH})$ of common antioxidants $(\mathrm{YH})$ in solution at $298.15 \mathrm{~K}$.

$\Delta S^{\circ}\left(14 \mathrm{RH}^{\bullet+}\right)$ and $\Delta S^{\circ}\left(16 \mathrm{RH}^{\bullet+}\right)$. In all, the different entropy changes make $\Delta G_{\mathrm{HD}}^{\mathrm{o}}\left(15 \mathrm{RH}^{\bullet+}\right)$ be between $\Delta G_{\mathrm{HD}}^{\mathrm{o}}\left(14 \mathrm{RH}^{\bullet+}\right)$ and $\left.\Delta G_{\mathrm{HD}}^{\mathrm{o}} 16 \mathrm{RH}^{\bullet+}\right)$.

If the $\Delta G_{\mathrm{HD}}^{\mathrm{o}}\left(\mathrm{XRH}^{\bullet+}\right)$ values of $17 \mathrm{XRH}^{\bullet+}$ are compared with that of their parent Hantzsch ester radical cations (denoted as $\mathrm{HEH}_{2}^{\bullet+}, \Delta G_{\mathrm{HD}}^{\mathrm{o}}\left(\mathrm{HEH}_{2}^{\bullet+}\right)=25.28 \mathrm{kcal} / \mathrm{mol}$, calculated in this work) without any substituent in the 4-position (Figure 1), $3 \mathrm{RH}^{\bullet+}, 8 \mathrm{RH}^{\bullet+}, 11 \mathrm{RH}^{\bullet+}, 13 \mathrm{RH}^{\bullet+}$, and $14 \mathrm{RH}^{\bullet+}$ have larger $\Delta G_{\mathrm{HD}}^{\mathrm{o}}\left(\mathrm{XRH}^{\bullet+}\right)$ values $(25.64-31.25 \mathrm{kcal} / \mathrm{mol})$ than $\mathrm{HEH}_{2}^{\bullet+}$, while others have smaller $\Delta G_{\mathrm{HD}}^{\mathrm{o}}\left(\mathrm{XRH}^{\bullet+}\right)$ values $(19.35-24.71$ $\mathrm{kcal} / \mathrm{mol})$ than $\mathrm{HEH}_{2}^{\circ+}(25.28 \mathrm{kcal} / \mathrm{mol})$. It is well known that $\mathrm{NADH}$ (Scheme 1), which has the typical 1,4-dihydropyridine structure in the redox core same as XRH and $\mathrm{HEH}_{2},{ }^{3-5}$ is an important redox coenzyme as a hydrogen and electron carrier in vivo. ${ }^{23-28}$ Figure 1 also presents $\Delta G_{\mathrm{HD}}^{\mathrm{o}}\left(\mathrm{NADH}^{\bullet+}\right)(23.90$ $\mathrm{kcal} / \mathrm{mol}$, computed in this work), which was clearly lower than the $\Delta G_{\mathrm{HD}}^{\mathrm{o}}\left(\mathrm{HEH}_{2}^{\bullet+}\right)$ value $(25.28 \mathrm{kcal} / \mathrm{mol})$, even though they all have the 1,4-dihydropyridine structure. $\Delta G_{\mathrm{HD}}^{\mathrm{o}}\left(\mathrm{NADH}^{\bullet+}\right)(23.90 \mathrm{kcal} / \mathrm{mol})$ is rightly among the range of $17 \Delta G_{\mathrm{HD}}^{\mathrm{o}}\left(\mathrm{XRH}^{\bullet+}\right)$ values $(19.35-31.25 \mathrm{kcal} / \mathrm{mol})$. Since $\mathrm{NADH}^{\bullet+}$ has excellent antioxidant activity, ${ }^{28}$ it is safe to infer that $17 \mathrm{XRH}^{\bullet+}$ should belong to excellent hydrogen atom donors. These data indicate that substituents on the 4-position and 2,3,5,6-positions have a significant effect on the thermodynamics of 1,4-dihydropyridine releasing $\mathrm{H}^{\bullet}$, and the Gibbs free energies of the 1,4-dihydropyridine radical cation structure $\left(\mathrm{DPH}^{\bullet+}\right)$ releasing $\mathrm{H}^{\bullet}\left[\Delta G_{\mathrm{HD}}^{\mathrm{o}}\left(\mathrm{DPH}^{\bullet+}\right)\right]$ may be between 19 and $32 \mathrm{kcal} / \mathrm{mol}$.

For typical antioxidants (defined as $\mathrm{YH}$ in this work) such as ascorbic acid $\left(\mathrm{AscH}_{2}\right)$, vitamin $\mathrm{E}(\mathrm{VE}), 2,6-{ }^{\mathrm{t}} \mathrm{Bu}_{2}-4-\mathrm{CH}_{3}-\mathrm{PhOH}$ (BHT), and the NADH coenzyme, the Gibbs free energy of $\mathrm{YH}$ releasing $\mathrm{H}^{\bullet}$ [denoted as $\Delta G_{\mathrm{HD}}^{\mathrm{o}}(\mathrm{YH})$ ] reflects the antioxidant activity to a large extent. ${ }^{29}$ It is true that for some antioxidants with phenolic hydroxyl or polar hydroxyl in the molecular structure, such as $\mathrm{AscH}_{2}, \mathrm{VE}$, and BHT, sometimes, the antioxidant process undergoes sequential proton loss electron transfer ${ }^{30}$ or proton-coupled electron transfer. ${ }^{29}$ As for $\mathrm{XRH}^{\bullet+}$, the antioxidant activity experiences the hydrogen atom-transfer mechanism (HAT) to give stable $\mathrm{XH}^{+}$directly. In this work, we focus on comparing the hydrogen-atom-donating ability between $\mathrm{XRH}^{\bullet+}$ and common antioxidants in HAT.

For comparison, we tried to obtain the Gibbs free energy changes of common excellent antioxidants $(\mathrm{YH})$ releasing hydrogen atoms [denoted as $\Delta G_{\mathrm{HD}}^{\mathrm{o}}(\mathrm{YH}), \Delta G_{\mathrm{HD}}^{\mathrm{o}}(\mathrm{YH})=$ $\left.\operatorname{BDEF}(\mathrm{YH})-4.9 \mathrm{kcal} / \mathrm{mol}^{29,31}\right]$ and compare the $\Delta G_{\mathrm{HD}}^{\mathrm{o}}(\mathrm{YH})$ values with $\Delta G_{\mathrm{HD}}^{\mathrm{o}}\left(\mathrm{XRH}^{\bullet+}\right)$ in this work (Figure 2). As shown in Figure 2, the $\Delta G_{\mathrm{HD}}^{\mathrm{o}}(\mathrm{YH})$ values of common antioxidants range from $59.1 \mathrm{kcal} / \mathrm{mol}$ for riboflavin to $81.3 \mathrm{kcal} / \mathrm{mol}$ for catechol, while the $\Delta G_{\mathrm{HD}}^{\mathrm{o}}\left(\mathrm{XRH}^{\bullet+}\right)$ values $(19.35-31.25 \mathrm{kcal} /$ $\mathrm{mol})$ of $17 \mathrm{XRH}^{\bullet+}$ are significantly smaller than the $\Delta G_{\mathrm{HD}}^{\mathrm{o}}(\mathrm{YH})$ values (smaller by $27-62 \mathrm{kcal} / \mathrm{mol}$ ). In conclusion, the thermodynamic data indicate that all 17 $\mathrm{XRH}^{\bullet+}$ have potentially better antioxidant activity in chemical reactions than common antioxidants.

To assess the applicability of these $\mathrm{XRH}^{\bullet+}$ in quenching common radicals $\left(\mathrm{R}^{\bullet}\right)$ in organic synthesis chemistry, we obtained the Gibbs free energies of common $\mathrm{R}^{\bullet}$ absorbing hydrogen atoms [denoted as $\Delta G_{\mathrm{HA}}^{\mathrm{o}}\left(\mathrm{R}^{\bullet}\right), \Delta G_{\mathrm{HA}}^{\mathrm{o}}\left(\mathrm{R}^{\bullet}\right)=$ $\left.-\operatorname{BDFE}(\mathrm{R}-\mathrm{H})+4.9 \mathrm{kcal} / \mathrm{mol}^{29,31}\right]$, as seen in Table 2 .

Table 2. Gibbs Free Energies of Common $\mathbf{R}^{\bullet}$ Absorbing Hydrogen Atoms $\left[\Delta G_{\mathrm{HA}}^{\mathrm{o}}\left(\mathrm{R}^{\bullet}\right)\right]$ in Acetonitrile $(\mathrm{kcal} / \mathrm{mol})^{29}$

\begin{tabular}{|c|c|c|c|}
\hline $\mathrm{R}-\mathrm{H}$ & resulting radical types & solvents & $\Delta G_{\mathrm{HA}}^{\mathrm{o}}\left(\mathrm{R}^{\bullet}\right)^{a}$ \\
\hline TEMPO ${ }^{\bullet}$ & O-radical & $\mathrm{CH}_{3} \mathrm{CN}$ & 61.6 \\
\hline $2,4,6-t \mathrm{Bu}_{3}-\mathrm{PhO}^{\bullet}$ & O-radical & $\mathrm{CH}_{3} \mathrm{CN}$ & 72.2 \\
\hline$t \mathrm{Bu}_{2} \mathrm{NO}^{\bullet}$ & O-radical & $\mathrm{CH}_{3} \mathrm{CN}$ & 60.3 \\
\hline $\operatorname{PrNH}^{\bullet}$ & $\mathrm{N}$-radical & $\mathrm{CH}_{3} \mathrm{CN}$ & 83.7 \\
\hline $\mathrm{Et}_{2} \mathrm{~N}^{\bullet}$ & $\mathrm{N}$-radical & $\mathrm{CH}_{3} \mathrm{CN}$ & 79.3 \\
\hline $\mathrm{tBuNH}^{\bullet}$ & $\mathrm{N}$-radical & $\mathrm{CH}_{3} \mathrm{CN}$ & 83.9 \\
\hline $\mathrm{C}_{6} \mathrm{H}_{5}-\mathrm{CH}_{2}^{\bullet}$ & C-radical & $\mathrm{CH}_{3} \mathrm{CN}$ & 82.1 \\
\hline $\mathrm{CpFe}(\mathrm{CO})_{2}^{\bullet}$ & Fe-radical & $\mathrm{CH}_{3} \mathrm{CN}$ & 45.4 \\
\hline $\mathrm{CpRu}(\mathrm{CO})_{2}^{\bullet}$ & Ru-radical & $\mathrm{CH}_{3} \mathrm{CN}$ & 53.3 \\
\hline $\mathrm{CpCr}(\mathrm{CO})_{3}^{\bullet}$ & Cr-radical & $\mathrm{CH}_{3} \mathrm{CN}$ & 56.6 \\
\hline $\mathrm{CpMo}(\mathrm{CO})_{3}^{\bullet}$ & Mo-radical & $\mathrm{CH}_{3} \mathrm{CN}$ & 57.5 \\
\hline $\mathrm{CpW}(\mathrm{CO})_{3}^{\circ}$ & W-radical & $\mathrm{CH}_{3} \mathrm{CN}$ & 60.7 \\
\hline $\mathrm{Mn}\left((\mathrm{CO})_{5}^{\bullet}\right.$ & Mn-radical & $\mathrm{CH}_{3} \mathrm{CN}$ & 57.9 \\
\hline $\operatorname{Re}(\mathrm{CO})_{5}^{\bullet}$ & Re-radical & $\mathrm{CH}_{3} \mathrm{CN}$ & 63.0 \\
\hline${ }^{a} \Delta G_{\mathrm{HA}}^{\mathrm{o}}\left(\mathrm{R}^{\bullet}\right)=-$ & $\mathrm{E}(\mathrm{R}-\mathrm{H})+4.9 \mathrm{kca}$ & & \\
\hline
\end{tabular}

Since the charged molecules are very sensitive to solvents and their reactivity may depend on the polarity of the solvents, we compare the $\Delta G_{\mathrm{HA}}^{\mathrm{o}}\left(\mathrm{R}^{\bullet}\right)$ with $\Delta G_{\mathrm{HD}}^{\mathrm{o}}\left(\mathrm{XRH}^{\bullet+}\right)$ in the same solvent (acetonitrile). As reported in the literature, ${ }^{29}$ the $\Delta G_{\mathrm{HA}}^{\mathrm{o}}\left(\mathrm{R}^{\bullet}\right)$ values of the $\mathrm{O}-\mathrm{H}$ bond (such as TEMPO ${ }^{\bullet}, 2,4,6-$ $t \mathrm{Bu}_{3}-\mathrm{PhO}^{\bullet}$, and $t \mathrm{Bu}_{2} \mathrm{NO}^{\bullet}$ ) range from 60.3 to $72.2 \mathrm{kcal} / \mathrm{mol}$, the $\Delta G_{\mathrm{HA}}^{\mathrm{o}}\left(\mathrm{R}^{\bullet}\right)$ values of the $\mathrm{N}-\mathrm{H}$ bond (such as $\mathrm{PrNH}^{\bullet}$, $\mathrm{Et}_{2} \mathrm{~N}^{\bullet}$, and $\mathrm{tBuNH}^{\bullet}$ ) range from 79.3 to $83.9 \mathrm{kcal} / \mathrm{mol}$, and the $\Delta G_{\mathrm{HA}}^{\mathrm{o}}\left(\mathrm{R}^{\bullet}\right)$ values of the $\mathrm{M}-\mathrm{H}$ bond [such as $\mathrm{CpFe}(\mathrm{CO})_{2}{ }^{\bullet}$, $\mathrm{CpCr}(\mathrm{CO})_{3}{ }^{\bullet}, \mathrm{Mn}(\mathrm{CO})_{5}{ }^{\circ}$, and $\left.\operatorname{Re}(\mathrm{CO})_{5}{ }^{\circ}\right]$ range from 45.4 to $63.0 \mathrm{kcal} / \mathrm{mol}$. Obviously, the $\Delta G_{\mathrm{HA}}^{\mathrm{o}}\left(\mathrm{R}^{\bullet}\right)$ values (45.4-83.9 


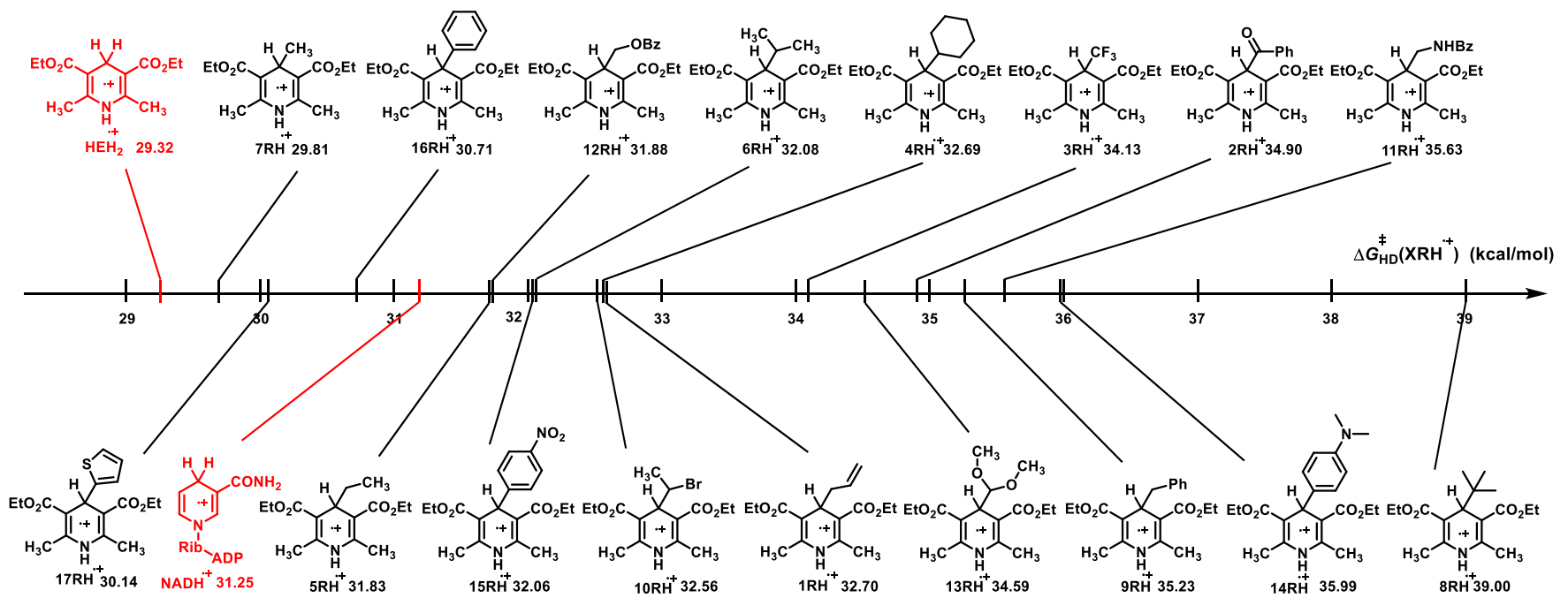

Figure 3. Comparison of $\Delta G_{\mathrm{HD}}^{\neq}\left(\mathrm{XRH}^{\bullet+}\right)$ among the $17 \mathrm{XRH}^{\bullet+}$ at $298.15 \mathrm{~K}$.

$\mathrm{kcal} / \mathrm{mol}$ ) are all significantly higher than the $\Delta G_{\mathrm{HD}}^{\mathrm{o}}\left(\mathrm{XRH}^{\bullet+}\right)$ values of $17 \mathrm{XRH}^{++}(19.35-31.25 \mathrm{kcal} / \mathrm{mol})$, which indicate that the Gibbs free energy changes of $\mathrm{R}^{\bullet}$ quenching reactions by $17 \mathrm{XRH}^{\bullet+}\left(\mathrm{XRH}^{\bullet+}+\mathrm{R}^{\bullet} \rightarrow \mathrm{XR}^{+}+\mathrm{RH}\right)$ are large negative values $\left[\Delta G^{\mathrm{o}}\left(\mathrm{XRH}^{\bullet+} / \mathrm{R}^{\bullet}\right) \ll 0\right] ;$ therefore, the radical quenching reactions are thermodynamically favorable and very easy to happen in solution.

Since we have obtained the Gibbs free energy of $\mathrm{XRH}^{\bullet+}$ releasing $\mathrm{R}^{\bullet}\left[\Delta G_{\mathrm{RD}}^{\mathrm{o}}\left(\mathrm{XRH}^{\bullet+}\right)\right.$ values $]$ in our previous work, ${ }^{16}$ the $\Delta G_{\mathrm{RD}}^{\mathrm{o}}\left(\mathrm{XRH}^{\bullet+}\right)$ values of $\mathrm{XRH}^{\bullet+}$ releasing $\mathrm{R}^{\bullet}$ range from -12.15 to $26.85 \mathrm{kcal} / \mathrm{mol}$, while the $\Delta G_{\mathrm{HD}}^{\circ}\left(\mathrm{XRH}^{\bullet+}\right)$ values of $\mathrm{XRH}^{\bullet+}$ releasing $\mathrm{H}^{\bullet}$ range from 29.81 to $39.00 \mathrm{kcal} / \mathrm{mol}$. If the $\Delta G_{\mathrm{RD}}^{\mathrm{o}}\left(\mathrm{XRH}^{\bullet+}\right)$ and $\Delta G_{\mathrm{HD}}^{\mathrm{o}}\left(\mathrm{XRH}^{\bullet+}\right)$ of one parent structure are compared, the margin value between them is denoted as $\Delta \Delta G^{\circ}(\mathrm{H}-\mathrm{R}) \quad\left[\Delta \Delta G^{\circ}(\mathrm{H}-\mathrm{R})=\Delta G_{\mathrm{HD}}^{\mathrm{o}}\left(\mathrm{XRH}^{\bullet+}\right)-\right.$ $\left.\Delta G_{\mathrm{RD}}^{\mathrm{o}}\left(\mathrm{XRH}^{\bullet+}\right)\right]$. The $\Delta \Delta G^{\mathrm{o}}(\mathrm{H}-\mathrm{R})$ values range from -2.25 $\left(16 \mathrm{RH}^{\bullet+}\right)$ to $38.58 \mathrm{kcal} / \mathrm{mol}\left(8 \mathrm{RH}^{\bullet+}\right)$. Among the $17 \mathrm{XRH}^{\bullet+}$ structures examined, the $\Delta \Delta G^{\circ}(\mathrm{H}-\mathrm{R})$ values of $13 \mathrm{XRH}^{\circ+}$ $\left(1 \mathrm{RH}^{\circ+}-13 \mathrm{RH}^{\bullet+}\right)$ are greater than $15 \mathrm{kcal} / \mathrm{mol}$, which means that the $\Delta G_{\mathrm{HD}}^{\mathrm{o}}\left(\mathrm{XRH}^{\circ+}\right)$ value is very much higher than $\Delta G_{\mathrm{RD}}^{\mathrm{o}}\left(\mathrm{XRH}^{\bullet+}\right)$ for $1 \mathrm{RH}^{\bullet+}-13 \mathrm{RH}^{\bullet+}$. Further checking the structure, the substituents in $1 \mathrm{RH}^{\circ+}-13 \mathrm{RH}^{\bullet+}$ are nonaromatic substituents. That is to say, $\mathrm{XRH}^{\circ+}$ with nonaromatic substituents tend to release $\mathrm{R}^{\bullet}$ instead of $\mathrm{H}^{\bullet}$ to quench radicals. Since 4-substituted Hantzsch esters (XRH, Scheme 1) are known as dipine drugs, if dipine drugs with nonaromatic substituents are used to treat hypertensive and cardiovascular diseases, we should pay more attention to the possible alkylation of DNA or RNA and genotoxicity by dihydropyridine radical cations generated by a single electron oxidant or oxidoreductase in vivo. While the $\Delta \Delta G^{\circ}(\mathrm{H}-\mathrm{R})$ values of 4 $\mathrm{XRH}^{\circ+}\left(14 \mathrm{RH}^{\circ+}-17 \mathrm{RH}^{\circ+}\right)$ are less than $6.5 \mathrm{kcal} / \mathrm{mol}$, the $\Delta \Delta G^{\circ}(\mathrm{H}-\mathrm{R})$ values of $14 \mathrm{RH}^{\circ+}, 16 \mathrm{RH}^{\circ+}$, and $17 \mathrm{RH}^{\circ+}$ are $-0.65,-2.25$, and $-1.76 \mathrm{kcal} / \mathrm{mol}$, respectively. The $\Delta \Delta G^{\circ}(\mathrm{H}-\mathrm{R})$ are negative values, which indicate that $14 \mathrm{RH}^{\circ+}, 16 \mathrm{RH}^{\circ+}$, and $17 \mathrm{RH}^{\circ+}$ tend to release $\mathrm{H}^{\bullet}$ instead of $\mathrm{R}^{\bullet}$ to quench radicals. From further analysis on the relevance between the chemical structure and $\Delta \Delta G^{\circ}(\mathrm{H}-\mathrm{R})$ values, it is evident that $\mathrm{R}$ substituents in $14 \mathrm{RH}^{\bullet+}, 16 \mathrm{RH}^{\bullet+}$, and $17 \mathrm{RH}^{\bullet+}$ are aromatic substituents, that is, $4-\mathrm{NMe}_{2}-\mathrm{Ph}-, \mathrm{Ph}$-, and 2thiophene, respectively. Therefore, it is safe to say that whether $\mathrm{XRH}^{\bullet+}$ is an excellent antioxidant is decided by the $\mathrm{R}$ substituents in the 4-position from thermodynamics. $\mathrm{XRH}^{\circ+}$ with nonaromatic substituents tend to release $\mathrm{R}^{\bullet}$ instead of $\mathrm{H}^{\bullet}$ to quench radicals. $\mathrm{XRH}^{\bullet+}$ with aromatic substituents tend to release $\mathrm{H}^{\bullet}$ and be used as antioxidants, but not all aromatic substituted Hantzsch esters are excellent antioxidants, such as $15 \mathrm{RH}^{\circ+}$.

Activation Free Energy $\left[\Delta G_{\mathrm{HD}}^{\neq}\left(\mathrm{XRH}^{\bullet+}\right)\right] . \Delta G_{\mathrm{HD}}^{\neq}\left(\mathrm{XRH}^{\bullet+}\right)$ is the characteristic physical parameter ${ }^{32}$ of $\mathrm{XRH}^{\bullet+}$ and reflects the kinetic properties of $\mathrm{XRH}^{\bullet+}$ releasing $\mathrm{H}^{\bullet}$ with no catalyst or substrate radicals. $\Delta G_{\mathrm{HD}}^{\neq}\left(\mathrm{XRH}^{\bullet+}\right)$ values of $17 \mathrm{XRH}^{\bullet+}$ are presented in Figure 3. Obviously, the $\Delta G_{\mathrm{HD}}^{\neq}\left(\mathrm{XRH}^{\bullet+}\right)$ values vary from $29.81\left(7 \mathrm{RH}^{\bullet+}\right)$ to $39.00 \mathrm{kcal} / \mathrm{mol}\left(8 \mathrm{RH}^{\bullet+}\right)$, and the corresponding reaction rate constants $\left(k_{\mathrm{H}}\right)$ range from $8.71 \times$ $10^{-10}$ to $1.60 \times 10^{-16} \mathrm{M}^{-1} \mathrm{~s}^{-1}$ at $298.15 \mathrm{~K}$, according to the Erying equation $k_{\mathrm{H}}=\left(k_{\mathrm{B}} T / h\right) \exp \left(-\Delta G^{\neq} / R T\right){ }^{33}$

If the $\Delta G_{\mathrm{HD}}^{\neq}\left(\mathrm{XRH}^{\bullet+}\right)$ values of $17 \mathrm{XRH}^{\bullet+}(29.81-39.00$ $\mathrm{kcal} / \mathrm{mol}$ ) are compared with that of their parent $\mathrm{HEH}_{2}^{++}$ $\left[\Delta G_{\mathrm{HD}}^{\neq}\left(\mathrm{HEH}_{2}^{\circ+}\right)=29.32 \mathrm{kcal} / \mathrm{mol}\right.$, computed in this work $]$, it is found that all $17 \Delta G_{\mathrm{HD}}^{\neq}\left(\mathrm{XRH}^{\circ+}\right)$ values are higher than $\Delta G_{\mathrm{HD}}^{\neq}\left(\mathrm{HEH}_{2}^{\circ+}\right)$, which means that the R substituents in the 4position make $\mathrm{XRH}^{\bullet+}$ harder to release hydrogen atoms, despite the electronegativity, $\mathrm{R}^{\bullet}$ stability, steric hindrance, and so on.

From Figure 3, it is found that the activation free energy of the $\mathrm{NADH}$ radical cation releasing $\mathrm{H}^{\bullet}\left[\Delta G_{\mathrm{HD}}^{\neq}\left(\mathrm{NADH}^{\bullet+}\right)\right.$, computed in this work] is $31.25 \mathrm{kcal} / \mathrm{mol}$. The $\Delta G_{\mathrm{HD}}^{f}\left(\mathrm{NADH}^{\circ+}\right)$ value $(31.25 \mathrm{kcal} / \mathrm{mol})$ is higher than $\Delta G_{\mathrm{HD}}^{\neq}\left(\mathrm{HEH}_{2}^{\circ+}\right)(29.32 \mathrm{kcal} / \mathrm{mol})$, which indicates that $\mathrm{HEH}_{2}^{\circ+}$ has better hydrogen-atom-donor reactivity than $\mathrm{NADH}^{\bullet+}$ from the kinetics. Moreover, $\Delta G_{\mathrm{HD}}^{\prime}\left(\mathrm{NADH}^{\bullet+}\right)$ $(31.25 \mathrm{kcal} / \mathrm{mol})$ is rightly among the $17 \Delta G_{\mathrm{HD}}^{\neq}\left(\mathrm{XRH}^{\bullet+}\right)$ values in the range of $29.81-39.00 \mathrm{kcal} / \mathrm{mol}$. Since $\mathrm{NADH}^{\circ+}$ is an excellent radical quencher, ${ }^{28} 17 \mathrm{XRH}^{\bullet+}$ should be excellent antioxidant reagents too. Nevertheless, the high activation free energies $\left[\Delta G_{\mathrm{HD}}^{\neq}\left(\mathrm{XRH}^{\bullet+}\right)>21 \mathrm{kcal} / \mathrm{mol}\right]$ indicate that releasing $\mathrm{H}^{\bullet}$ from all $17 \mathrm{XRH}^{\bullet+}$ is kinetically unfavorable spontaneous behavior and extremely slow in acetonitrile without any catalyst or hydrogen atom acceptors at room temperature. Considering the same 1,4-dihydropyridine core structure of $\mathrm{XRH}^{\bullet+}, \mathrm{HEH}_{2}^{\bullet+}$, and $\mathrm{NADH}^{\bullet+}$, the activation free energies of the 1,4-dihydropyridine radical cation structure $\left(\mathrm{DPH}^{\bullet+}\right)$ releasing $\mathrm{H}^{\bullet}\left[\Delta G_{\mathrm{HD}}^{f}\left(\mathrm{DPH}^{\bullet+}\right)\right]$ may be between 29 and $39 \mathrm{kcal} / \mathrm{mol}$ in acetonitrile. 
To further examine the interrelationship between thermodynamic driving forces and kinetic properties, the correlation between $\Delta G_{\mathrm{HD}}^{\mathrm{o}}\left(\mathrm{XRH}^{\bullet+}\right)$ and $\Delta G_{\mathrm{HD}}^{\neq}\left(\mathrm{XRH}^{\bullet+}\right)$ is illustrated in Figure 4. It is clear that there is a certain correlation between

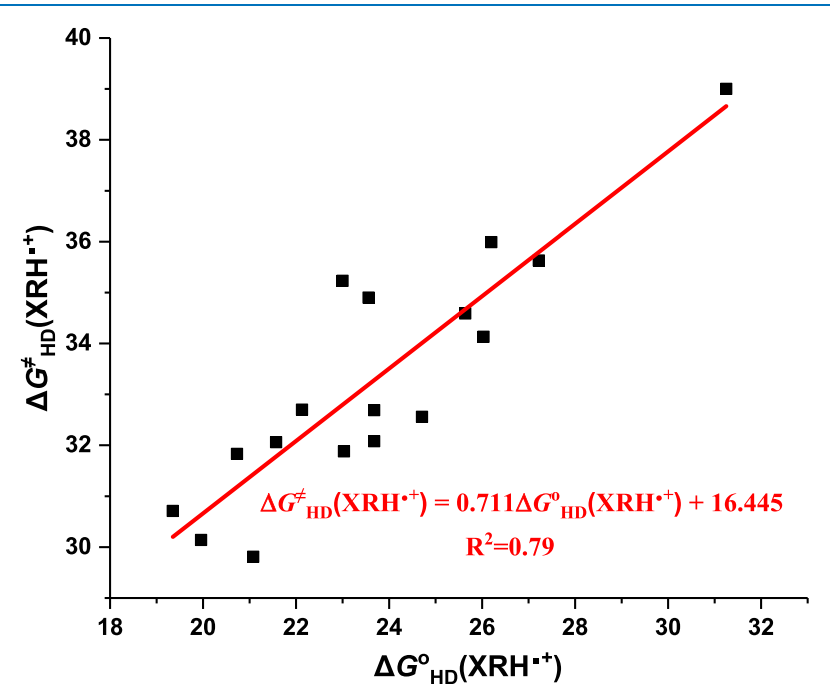

Figure 4. Correlation between the $\Delta G_{\mathrm{HD}}^{\neq}\left(\mathrm{XRH}^{\bullet+}\right)$ and $\Delta G_{\mathrm{HD}}^{\mathrm{o}}\left(\mathrm{XRH}^{\bullet+}\right)$ of $17 \mathrm{XRH}^{\bullet+}$ releasing $\mathrm{H}^{\bullet}$.

$\Delta G_{\mathrm{HD}}^{\mathrm{o}}\left(\mathrm{XRH}^{\bullet+}\right)$ and $\Delta G_{\mathrm{HD}}^{\neq}\left(\mathrm{XRH}^{\bullet+}\right)$, that is, $\Delta G_{\mathrm{HD}}^{\neq}\left(\mathrm{XRH}^{\bullet+}\right)$ increases in company with the increase of $\Delta G_{\mathrm{HD}}^{\mathrm{o}}\left(\mathrm{XRH}^{\bullet+}\right)$. However, for all $17 \mathrm{XRH}^{\bullet+}$, no good linear correlation was found between $\Delta G_{\mathrm{HD}}^{\neq}\left(\mathrm{XRH}^{\bullet+}\right)$ and $\Delta G_{\mathrm{HD}}^{\mathrm{o}}\left(\mathrm{XRH}^{\bullet+}\right){ }^{34}$ This correlation shows that the activation free energy is decided by complex factors and not the only factor of Gibbs free energy, although it is the important and decisive parameter. The linear correlation was also fitted to give the equation $\Delta G_{\mathrm{HD}}^{\neq}\left(\mathrm{XRH}^{\bullet+}\right)$ $=0.711 \Delta G_{\mathrm{HD}}^{\mathrm{o}}\left(\mathrm{XRH}^{\bullet+}\right)+16.445\left(R^{2}=0.79\right)$, which means that $\Delta G_{\mathrm{HD}}^{\neq}\left(\mathrm{XRH}^{\bullet+}\right)$ can be roughly estimated when $\Delta G_{\mathrm{HD}}^{\mathrm{o}}\left(\mathrm{XRH}^{\bullet+}\right)$ are obtained.

Changes of Entropy $\Delta S_{\mathrm{HD}}^{\circ}\left(\mathrm{XRH}^{\bullet+}\right)$ and $\Delta S_{\mathrm{HD}}\left(\mathrm{XRH}^{\bullet+}\right)$. The entropy changes and activation entropies of $17 \mathrm{XRH}^{\bullet+}$ releasing $\mathrm{H}^{\bullet}$ [denoted as $\Delta S_{\mathrm{HD}}^{\mathrm{o}}\left(\mathrm{XRH}^{\bullet+}\right)$ and $\Delta S_{\mathrm{HD}}^{\neq}\left(\mathrm{XRH}^{\bullet+}\right)$ in this work, respectively] are calculated from the corresponding enthalpies and Gibbs free energies (Table 3). From Table 3, we can see that $\Delta S_{\mathrm{HD}}^{\mathrm{o}}\left(\mathrm{XRH}^{\bullet+}\right)$ vary from $20.56\left(17 \mathrm{RH}^{\bullet+}\right)$ to $27.52 \mathrm{cal} \mathrm{mol}^{-1} \mathrm{~K}^{-1}\left(6 \mathrm{RH}^{\bullet+}\right)$, while $\Delta S_{\mathrm{HD}}^{\neq}\left(\mathrm{XRH}^{\bullet+}\right)$ vary from $-3.79\left(15 \mathrm{RH}^{\bullet+}\right)$ to $4.45 \mathrm{cal} \mathrm{mol}^{-1} \mathrm{~K}^{-1}\left(6 \mathrm{RH}^{\bullet+}\right)$. It is found that $\Delta S_{\mathrm{HD}}^{\mathrm{o}}\left(\mathrm{XRH}^{\bullet+}\right)$ are all positive values bigger than $20 \mathrm{cal}$ $\mathrm{mol}^{-1} \mathrm{~K}^{-1}$, which indicates that the reaction process of $\mathrm{XRH}^{\bullet+}$ releasing $\mathrm{H}^{\bullet}$ is in company with a large entropy increase. This is quite reasonable since the releasing $\mathrm{H}^{\bullet}$ reaction involves cleavage of one molecule to two segments, which increases the freedom of the system. On the other hand, the variation of $\Delta S_{\mathrm{HD}}^{\neq}\left(\mathrm{XRH}^{\bullet+}\right)\left(-3.79-4.45 \mathrm{cal} \mathrm{mol}^{-1} \mathrm{~K}^{-1}\right)$ is less than $\pm 5 \mathrm{cal}$ $\mathrm{mol}^{-1} \mathrm{~K}^{-1}$, indicating that transition states of $\mathrm{XRH}^{\bullet+}$ do not undergo drastic structural changes compared with the initial state. In the elementary step of $\mathrm{XRH}^{\bullet+}$ releasing $\mathrm{H}^{\bullet}$, the $\mathrm{C}-\mathrm{H}$ bond does not completely break at the transition state (TS), while the reaction products completely break to $\mathrm{XR}^{+}$and $\mathrm{H}^{\circ}$. Therefore, the structure of TS is reactant-like instead of product-like. In addition, the $\mathrm{XR}^{+}$and $\mathrm{H}^{\bullet}$ are charged structures and have a stronger solvation effect. On the basis of the above analysis, it is reasonable that $\Delta S_{\mathrm{HD}}^{\mathrm{o}}\left(\mathrm{XRH}^{\bullet+}\right)$ are large positive $\left(20.56-27.52 \mathrm{cal} \mathrm{mol}^{-1} \mathrm{~K}^{-1}\right)$, but the $\Delta S_{\mathrm{HD}}^{\neq}\left(\mathrm{XRH}^{\bullet+}\right)$ are very small close to $0(-3.79-4.45 \mathrm{cal}$ $\left.\mathrm{mol}^{-1} \mathrm{~K}^{-1}\right)$.

\section{CONCLUSIONS}

This work focuses on the hydrogen-atom-donating ability of the key intermediate $\mathrm{XRH}^{\bullet+}$ generated from 4-substituted Hantzsch ester (XRH). Four characteristic physical chemistry parameters of $17 \mathrm{XRH}^{\bullet+}$ releasing $\mathrm{H}^{\bullet}, \Delta H_{\mathrm{HD}}^{\mathrm{o}}\left(\mathrm{XRH}^{\bullet+}\right)$, $\Delta G_{\mathrm{HD}}^{\mathrm{o}}\left(\mathrm{XRH}^{\bullet+}\right), \Delta H_{\mathrm{HD}}^{\neq}\left(\mathrm{XRH}^{\bullet+}\right)$, and $\Delta G_{\mathrm{HD}}^{\neq}\left(\mathrm{XRH}^{\bullet+}\right)$ were calculated using DFT and analyzed in detail. (1) The $\Delta G_{\mathrm{HD}}^{\mathrm{o}}\left(\mathrm{XRH}^{\bullet+}\right)$ values are all positive values larger than $19.35 \mathrm{kcal} / \mathrm{mol}(19.35-31.25 \mathrm{kcal} / \mathrm{mol})$, which means that it is very difficult for $\mathrm{XRH}^{\bullet+}$ to release $\mathrm{H}^{\bullet}$ at $298.15 \mathrm{~K}$ spontaneously in the absence of the hydrogen atom capturer. Nevertheless, $\Delta G_{\mathrm{HD}}^{\mathrm{o}}\left(\mathrm{XRH}^{\bullet+}\right)$ values of $17 \mathrm{XRH}^{\bullet+}$ are significantly smaller than that of common antioxidants such as ascorbic acid, $\mathrm{BHT}$, vitamin $\mathrm{E}$, and the $\mathrm{NADH}$ coenzyme. (2) The $\Delta G_{\mathrm{HD}}^{\neq}\left(\mathrm{XRH}^{\bullet+}\right)$ values span from 29.81 to $39.00 \mathrm{kcal} /$ mol, and the cleavage of the $\mathrm{C}-\mathrm{H}$ bond to release spontaneously $\mathrm{H}^{\bullet}$ in $\mathrm{XRH}^{\bullet+}$ is extremely slow in acetonitrile at room temperature. (3) $\Delta G_{\mathrm{HD}}^{\neq}\left(\mathrm{XRH}^{\bullet+}\right)$ increases in company with the increase of $\Delta G_{\mathrm{HD}}^{\mathrm{o}}\left(\mathrm{XRH}^{\bullet+}\right)$, but no simple linear correlations are found because the influence of 4substituent structures on $\Delta G_{\mathrm{HD}}^{\mathrm{o}}\left(\mathrm{XRH}^{\bullet+}\right)$ and $\Delta G_{\mathrm{HD}}^{\neq}\left(\mathrm{XRH}^{\bullet+}\right)$ is rather complicated. (4) If $\mathrm{R}$ is a nonaromatic substituent, $\mathrm{XRH}^{\bullet+}$ prefer to release $\mathrm{R}^{\bullet}$ to quench radicals; If $\mathrm{R}$ is an aromatic substituent, $\mathrm{XRH}^{\bullet+}$ prefer to release $\mathrm{H}^{\bullet}$ to quench radicals, but not all aromatic substituted Hantzsch esters are excellent antioxidants. The data and calculation method presented in this work would be helpful in applications of $\mathrm{XRH}^{\bullet+}$ as antioxidants and free-radical scavengers in organic chemistry and other related areas.

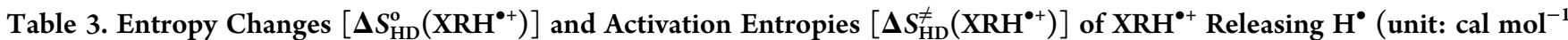
$\left.\mathrm{K}^{-1}\right)$

\begin{tabular}{|c|c|c|c|c|c|}
\hline XRH & $\Delta S_{\mathrm{HD}}^{\mathrm{o}}\left(\mathrm{XRH}^{\bullet++}\right)^{a}$ & $\Delta S_{\mathrm{HD}}^{\neq}\left(\mathrm{XRH}^{\bullet+}\right)^{b}$ & XRH & $\Delta S_{\mathrm{HD}}^{\mathrm{o}}\left(\mathrm{XRH}^{\bullet+}\right)^{a}$ & $\Delta S_{\mathrm{HD}}^{ \pm}\left(\mathrm{XRH}^{\bullet+}\right)^{b}$ \\
\hline $1 \mathrm{RH}$ & 27.17 & 1.48 & $10 \mathrm{RH}$ & 23.26 & 0.07 \\
\hline $2 \mathrm{RH}$ & 24.28 & -0.60 & $11 \mathrm{RH}$ & 23.10 & 0.39 \\
\hline $3 \mathrm{RH}$ & 25.26 & -0.45 & $12 \mathrm{RH}$ & 24.53 & 3.00 \\
\hline $4 \mathrm{RH}$ & 23.15 & 0.24 & $13 \mathrm{RH}$ & 24.62 & 2.53 \\
\hline $5 \mathrm{RH}$ & 25.91 & 0.72 & $14 \mathrm{RH}$ & 24.99 & 1.71 \\
\hline $6 \mathrm{RH}$ & 27.52 & 4.45 & $15 \mathrm{RH}$ & 21.09 & -3.79 \\
\hline $7 \mathrm{RH}$ & 24.32 & 2.99 & $16 \mathrm{RH}$ & 25.14 & -2.42 \\
\hline $8 \mathrm{RH}$ & 23.69 & 1.47 & $17 \mathrm{RH}$ & 20.56 & -3.28 \\
\hline 9RH & 25.27 & 1.23 & & & \\
\hline
\end{tabular}




\section{ASSOCIATED CONTENT}

\section{s) Supporting Information}

The Supporting Information is available free of charge at https://pubs.acs.org/doi/10.1021/acsomega.1c03872.

Coordinates of optimized structures and IRC energies of each $\mathrm{XRH}^{\bullet+}(\mathrm{PDF})$

\section{AUTHOR INFORMATION}

\section{Corresponding Author}

Maocai Yan - School of Pharmacy, Jining Medical University, Rizhao, Shandong 276800, P. R. China; 이이.org/00000002-1117-9398; Email: maocaiyan@mail.jnmc.edu.cn

\section{Authors \\ Guang-Bin Shen - School of Medical Engineering, Jining Medical University, Jining, Shandong 272000, P. R. China; (1) orcid.org/0000-0003-0449-7301 \\ Li Xie - School of Medical Engineering, Jining Medical University, Jining, Shandong 272000, P. R. China \\ Yun-Xia Wang - School of Medical Engineering, Jining Medical University, Jining, Shandong 272000, P. R. China \\ Teng-Yang Gong - School of Pharmacy, Jining Medical University, Rizhao, Shandong 276800, P. R. China \\ Bin-Yu Wang - School of Medical Engineering, Jining Medical University, Jining, Shandong 272000, P. R. China \\ Yu-He Hu - School of Medical Engineering, Jining Medical University, Jining, Shandong 272000, P. R. China \\ Yan-Hua Fu - College of Chemistry and Environmental Engineering, Anyang Institute of Technology, Anyang, Henan 455000, P. R. China}

Complete contact information is available at:

https://pubs.acs.org/10.1021/acsomega.1c03872

\section{Notes}

The authors declare no competing financial interest.

\section{ACKNOWLEDGMENTS}

This study was supported by the NSFC cultivation project of Jining Medical University (JYP2018KJ18 and JYP2019KJ25), the doctoral scientific research foundation of Jining Medical University (600841002), and the College Students' Innovative Training Plan Program of Jining Medical University (cx2020106).

\section{REFERENCES}

(1) (a) Gao, S.; Yan, N. Structural Basis of the Modulation of the Voltage-Gated Calcium Ion Channel Cav1.1 by Dihydropyridine Compounds. Angew. Chem., Int. Ed. 2021, 60, 3131-3137. (b) Mulder, P.; Litwinienko, G.; Lin, S.; MacLean, P. D.; Barclay, L. R. C.; Ingold, K. U. The L-Type Calcium Channel Blockers, Hantzsch 1,4-Dihydropyridines, Are Not Peroxyl Radical-Trapping, Chain-Breaking Antioxidants. Chem. Res. Toxicol. 2006, 19, 79-85. (c) Huang, J.; Buckley, N. A.; Isoardi, K. Z.; Chiew, A. L.; Isbister, G. K.; Cairns, R.; Brown, J. A.; Chan, B. S. Angiotensin Axis Antagonists Increase the Incidence of Haemodynamic Instability in Dihydropyridine Calcium Channel Blocker Poisoning. Clin. Toxicol. 2021, 59, 464-471.

(2) (a) Mendez, S. R.; Frank, R. C.; Stevenson, E. K.; Chung, M.; Silverman, M. G. Dihydropyridine Calcium Channel Blockers and the Risk of Severe COVID-19. Chest 2021, 160 (1), 89-93. (b) Pan, X.; Li, R.; Guo, H.; Zhang, W.; Xu, X.; Chen, X.; Ding, L. Dihydropyridine Calcium Channel Blockers Suppress the Transcription of PD-L1 by Inhibiting the Activation of STAT1. Front.
Pharmacol. 2021, 11, 539261. (c) Khot, S.; Auti, P. B.; Khedkar, S. A. Diversified Synthetic Pathway of 1, 4-Dihydropyridines: A Class of Pharmacologically Important Molecules. Mini-Rev. Med. Chem. 2021, 21, 135-149. (d) Sorkin, E. M.; Clissold, S. P.; Brogden, R. N. Nifedipine. Drugs 1985, 30, 182-274.

(3) (a) Pi, D.; Zhou, H.; Cui, P.; He, R.; Sui, Y. Silver-Catalyzed Biomimetic Transfer Hydrogenation of N-Heteroaromatics with Hantzsch Esters as NADH Analogues. ChemistrySelect 2017, 2, 3976-3979. (b) Zhu, X.-Q.; Zou, H.-L.; Yuan, P.-W.; Liu, Y.; Cao, L.; Cheng, J.-P. A Detailed Investigation into the Oxidation Mechanism of Hantzsch 1,4-dihydropyridines by Ethyl $\alpha$-cyanocinnamates and Benzyl-idenemalononitriles. J. Chem. Soc., Perkin Trans. 2 2000, 1857-1861. (c) Zhu, X.-Q.; Wang, H.-Y.; Wang, J.-S.; Liu, Y.-C. Application of $\mathrm{NAD}(\mathrm{P}) \mathrm{H}$ Model Hantzsch 1,4-Dihydropyridine as a Mild Reducing Agent in Preparation of Cyclo Compounds. J. Org. Chem. 2001, 66, 344-347.

(4) (a) Zhu, X.-Q.; Liu, Y.-C.; Cheng, J.-P. Which Hydrogen Atom Is First Transferred in the $\mathrm{NAD}(\mathrm{P}) \mathrm{H}$ Model Hantzsch Ester Mediated Reactions via One-Step and Multistep Hydride Transfer? J. Org. Chem. 1999, 64, 8980-8981. (b) Cheng, J.-P.; Lu, Y.; Zhu, X.Q.; Sun, Y.-K.; Bi, F.; He, J. Heterolytic and Homolytic N-H Bond Dissociation Energies of 4-Substituted Hantzsch 2,6-Dimethyl-1,4dihydropyridines and the Effect of One-Electron Transfer on the N-H Bond Activation. J. Org. Chem. 2000, 65, 3853-3857.

(5) (a) Zhu, X.-Q.; Zhao, B.-J.; Cheng, J.-P. Mechanisms of the Oxidations of $\mathrm{NAD}(\mathrm{P}) \mathrm{H}$ Model Hantzsch 1,4-Dihydropyridines by Nitric Oxide and Its Donor N-Methyl-N-nitrosotoluene-p-sulfonamide. J. Org. Chem. 2000, 65, 8158-8163. (b) Garden, S. J.; Guimarăes, C. R. W.; Corréa, M. B.; Oliveira, C. A. F.; Angelo da Cunha Pinto, A. C.; Alencastro, R. B. Synthetic and Theoretical Studies on the Reduction of Electron Withdrawing Group Conjugated Olefins Using the Hantzsch 1,4-Dihydropyridine Ester. J. Org. Chem. 2003, 68, 8815-8822.

(6) (a) Gao, Y.; Wang, B.; Gao, S.; Zhang, R.; Yang, C.; Sun, Z.; Liu, Z. Design and Synthesis of 1,4-Dihydropyridine and Cinnamic Acid Esters and Their Antioxidant Properties. Chem. Res. Chin. Univ. 2016, 32, 594-599. (b) López-Alarcón, C.; Navarrete, P.; Camargo, C.; Squella, J. A.; Núñez-Vergara, L. J. Reactivity of 1,4-Dihydropyridines toward Alkyl, Alkylperoxyl Radicals, and ABTS Radical Cation. Chem. Res. Toxicol. 2003, 16, 208-215. (c) Aruoma, O. I.; Smith, C.; Cecchini, R.; Evans, P. J.; Halliwell, B. Free Radical Scavenging and Inhibition of Lipid Peroxidation by Beta-blockers and by Agents that Interfere with Calcium Metabolism. Biochem. Pharmacol. 1991, 42, $735-743$.

(7) (a) Mak, I. T.; Weglicki, W. B. Comparative Antioxidant Activities of Propranolol, Nifedipine, Verapamil, and Diltiazem against Sarcolemmal Membrane Lipid Peroxidation. Circ. Res. 1990, 66, 1449-1452. (b) Mason, R. P.; Mak, I. T.; Trumbore, M. W.; Mason, P. E. Antioxidant Properties of Calcium Antagonists Related to Membrane Biophysical Interactions. Am. J. Cardiol. 1999, 84, 161221. (c) Diaz-Araya, G.; Godoy, L.; Naranjo, L.; Squella, J. A.; Letelier, M. E.; Núñez-Vergara, L. J. Antioxidant Effects of 1,4dihydropyridine and Nitroso Aryl Derivatives on the $\mathrm{Fe}^{+3}$ / ascorbatestimulated Lipid Peroxidation in Rat Brain Slices. Gen. Pharmacol. 1998, 31, 385-391.

(8) (a) Lupo, E.; Locher, R.; Weisser, B.; Velter, W. Vitro Antioxidant Activity of Calcium Antagonists against LDL Oxidation Compared with Alpha-tocopherol. Biochem. Biophys. Res. Commun. 1994, 203, 1803-1808. (b) Napoli, C.; Chiariello, M.; Palumbo, G.; Ambrosio, G. Calcium-channel Blockers Inhibit Human Lowdensity Lipoprotein Oxidation by Oxygen Radicals. Cardiovasc. Drugs Ther. 1996, 10, 417-424. (c) Sobal, G.; Menzel, E. J.; Sinzinger, H. Calcium Antagonists as Inhibitors of in Vitro Low-density Lipoprotein Oxidation and Glycation. Biochem. Pharmacol. 2001, 61, 373-379.

(9) (a) Velēna, A.; Zilbers, J.; Dubers, G. Derivatives of 1,4Dihydropyridines as Modulators of Ascorbate-induced Lipid Peroxidation and High-amplitude Swelling of Mitochondria, Caused by Ascorbate, Sodium Linoleate and Sodium Pyrophosphate. Cell 
Biochem. Funct. 1999, 17, 237-252. (b) Mak, I. T.; Boheme, P.; Weglicki, W. B. Antioxidant Effects of Calcium Channel Blockers against Free Radical Injury in Endothelial Cells. Correlation of Protection with Preservation of Glutathione Levels. Circ. Res. 1992, 70, 1099-1103. (c) Mak, I. T.; Boheme, P.; Weglicki, W. B. Protective Effects of Calcium Channel Blockers Against Free Radicalimpaired Endothelial Cell Proliferation. Biochem. Pharmacol. 1995, 50, $1531-1534$.

(10) Reviews: (a) Wang, P.-Z.; Chen, J.-R.; Xiao, W.-J. Hantzsch esters: an Emerging Versatile Class of Reagents in Photoredox Catalyzed Organic Synthesis. Org. Biomol. Chem. 2019, 17, 69366951. (b) Ye, S.; Wu, J. 4-Substituted Hantzsch Esters as Alkylation Reagents in Organic Synthesis. Acta Chim. Sin. 2019, 77, 814-831. (c) Milligan, J. A.; Phelan, J. P.; Badir, S. O.; Molander, G. A. Recent Advances in Alkyl Carbon-Carbon Bond Formation by Nickel/ Photoredox Cross-Coupling. Angew. Chem., Int. Ed. 2019, 58, 61526163.

(11) (a) Wangelin, A. J.; Konev, M. O.; Cardinale, L. PhotoredoxCatalyzed Addition of Carbamoyl Radicals to Olefins: A 1,4Dihydropyridine Approach. Chem.-Eur. J. 2020, 26, 8239-8243. (b) Wang, J.; Shao, Z.; Tan, K.; Tang, R.; Zhou, Q.; Xu, M.; Li, Y.-M.; Shen, Y. Synthesis of Amino Acids by Base-enhanced Photoredox Decarboxylative Alkylation of Aldimines. J. Org. Chem. 2020, 85, 9944-9954. (c) Liu, L.; Jiang, P.; Liu, Y.; Du, H.; Tan, J. Direct Radical Alkylation and Acylation of $2 \mathrm{H}$-indazoles Using Substituted Hantzsch Esters as Radical Reservoirs. Org. Chem. Front. 2020, 7, 2278-2283. (d) Schwarz, J. L.; Huang, H.-M.; Paulisch, T. O.; Glorius, F. Dialkylation of 1,3-Dienes by Dual Photoredox and Chromium Catalysis. ACS Catal. 2020, 10, 1621-1627.

(12) (a) Zhu, D.-L.; Wu, Q.; Li, H.-Y.; Li, H.-X.; Lang, J.-P. Hantzsch Ester as a Visible-Light Photoredox Catalyst for TransitionMetal-Free Coupling of Arylhalides and Arylsulfinates. Chem.-Eur. J. 2020, 26, 3484-3488. (b) Li, J.; Yang, X.-E.; Wang, S.-L.; Zhang, L.L.; Zhou, X.-Z.; Wang, S.-Y.; Ji, S.-J. Visible-Light-Promoted CrossCoupling Reactions of 4-Alkyl-1,4-dihydropyridines with Thiosulfonate or Selenium Sulfonate: A Unified Approach to Sulfides, Selenides, and Sulfoxides. Org. Lett. 2020, 22, 4908-4913. (c) Du, H.-W.; Sun, J.; Gao, Q.-S.; Wang, J.-Y.; Wang, H.; Xu, Z.; Zhou, M.-D. Synthesis of Monofluoroalkenes through Visible-Light-Promoted Defluorinative Alkylation of gem-Difluoroalkenes with 4-Alkyl-1,4dihydropyridines. Org. Lett. 2020, 22, 1542-1546.

(13) Liang, S.; Kumon, T.; Angnes, R. A.; Sanchez, M.; Xu, B.; Hammond, G. B. Synthesis of Alkyl Halides from Aldehydes via Deformylative Halogenation. Org. Lett. 2019, 21, 3848-3854. (b) Angnes, R. A.; Potnis, C.; Liang, S.; Correia, C. R. D.; Hammond, G. B. Photoredox-Catalyzed Synthesis of Alkylaryldiazenes: Formal Deformylative C-N Bond Formation with Alkyl Radicals. J. Org. Chem. 2020, 85, 4153-4164. (c) Wang, J.; Pang, Y.-B.; Tao, N.; Zeng, R.-S.; Zhao, Y. Mn-Enabled Radical-Based AlkylAlkyl Cross-Coupling Reaction from 4-Alkyl-1,4- dihydropyridines. J. Org. Chem. 2019, 84, 15315-15322.

(14) (a) Zhang, K.; Lu, L.-Q.; Jia, Y.; Wang, Y.; Lu, F.-D.; Pan, F.; Xiao, W.-J. Exploration of a Chiral Cobalt Catalyst for Visible-LightInduced Enantioselective Radical Conjugate Addition. Angew. Chem., Int. Ed. 2019, 131, 13509-13513. (b) Wang, X.; Li, H.; Qiu, G.; Wu, J. Substituted Hantzsch Esters as Radical Reservoirs with the Insertion of Sulfur Dioxide under Photoredox Catalysis. Chem. Commun. 2019, 55, 2062-2065. (c) Phelan, J. P.; Lang, S. B.; Sim, J.; Berritt, S.; Peat, A. J.; Billings, K.; Fan, L.; Molander, G. A. Open-Air Alkylation Reactions in Photoredox-Catalyzed DNA-Encoded Library Synthesis. J. Am. Chem. Soc. 2019, 141, 3723-3732. (d) Leeuwen, T.; Buzzetti, L.; Perego, L. A.; Melchiorre, P. A Redox-Active Nickel Complex that Acts as an Electron Mediator in Photochemical Giese Reactions. Angew. Chem., Int. Ed. 2019, 58, 4953-4957.

(15) (a) Goti, G.; Bieszczad, B.; Vega-Penaloza, A.; Melchiorre, P. Stereocontrolled Synthesis of 1,4-Dicarbonyl Compounds by Photochemical Organocatalytic Acyl Radical Addition to Enals. Angew. Chem., Int. Ed. 2019, 58, 1213-1217. (b) Nakajima, K.; Zhang, Y.; Nishibayashi, Y. Alkylation Reactions of Azodicarboxylate Esters with
4-Alkyl-1,4-Dihydropyridines under Catalyst-Free Conditions. Org. Lett. 2019, 21, 4642-4645.

(16) Shen, G.-B.; Xie, L.; Yu, H. Y.; Liu, J.; Fu, Y.-H.; Yan, M. Theoretical Investigation on the Nature of 4-Substituted Hantzsch Esters as Alkylation Agents. RSC Adv. 2020, 10, 31425-31434.

(17) (a) Becke, A. D. Density-functional Thermochemistry. 3. the Role of Exact Exchange. J. Chem. Phys. 1993, 98, 5648-5652. (b) Stephens, P. J.; Devlin, F. J.; Chabalowski, C. F.; Frisch, M. J. Abinitio Calculation of Vibrational Absorption and Circular-dichroism Spectra using Density-functional Force-fields. J. Phys. Chem. 1994, 98 , $11623-11627$.

(18) (a) Ditchfield, R.; Hehre, W. J.; Pople, J. A. Self-Consistent Molecular Orbital Methods. 9. Extended Gaussian-type Basis for Molecular-orbital Studies of Organic Molecules. J. Chem. Phys. 1971, 54, 724. (b) Hehre, W. J.; Ditchfield, R.; Pople, J. A. Self-Consistent Molecular Orbital Methods. 12. Further Extensions of Gaussian-type Basis Sets for Use in Molecular-orbital Studies of Organic-molecules. J. Chem. Phys. 1972, 56, 2257. (c) Hariharan, P. C.; Pople, J. A. Influence of Polarization Functions on Molecular-orbital Hydrogenation Energies. Theor. Chem. Acc. 1973, 28, 213-222.

(19) Grimme, S.; Ehrlich, S.; Goerigk, L. Effect of the Damping Function in Dispersion Corrected Density Functional Theory. J. Comput. Chem. 2011, 32, 1456-1465.

(20) Marenich, A. V.; Cramer, C. J.; Truhlar, D. G. Universal Solvation Model Based on Solute Electron Density and on a Continuum Model of the Solvent Defined by the Bulk Dielectric Constant and Atomic Surface Tensions. J. Phys. Chem. B 2009, 113, 6378-6396.

(21) Frisch, M. J.; Trucks, G. W.; Schlegel, H. B.; et al. Gaussian 09; Gaussian, Inc., 2013.

(22) Lu, T.; Chen, F. Multiwfn: A Multifunctional Wavefunction Analyzer. J. Comput. Chem. 2012, 33, 580-592.

(23) (a) Ali, M. A.; Hassan, A.; Sedenho, G. C.; Gonçalves, R. V.; Cardoso, D. R.; Crespilho, F. N. Operando Electron Paramagnetic Resonance for Elucidating the Electron Transfer Mechanism of Coenzymes. J. Phys. Chem. C 2019, 123, 16058-16064. (b) Zielonka, J.; Marcinek, A.; Adamus, J.; Gębicki, J. Direct Observation of NADH Radical Cation Generated in Reactions with One-Electron Oxidants. J. Phys. Chem. A 2003, 107, 9860-9864. (c) Saura, P.; Kaila, V. R. I. Energetics and Dynamics of Proton-Coupled Electron Transfer in the NADH/FMN Site of Respiratory Complex I. J. Am. Chem. Soc. 2019, $141,5710-5719$.

(24) (a) Li, F.; Li, Y.; Sun, L.; Chen, X.; An, X.; Yin, C.; Cao, Y.; Wu, H.; Song, H. Modular Engineering Intracellular NADH Regeneration Boosts Extracellular Electron Transfer of Shewanella oneidensis MR-1. ACS Synth. Biol. 2018, 7, 885-895. (b) Matsuzaki, S.; Kotake, Y.; Humphries, K. M. Identification of Mitochondrial Electron Transport Chain-Mediated NADH Radical Formation by EPR Spin-Trapping Techniques. Biochemistry 2011, 50, 1079210803. (c) Crane, E. J.; Parsonage, D.; Poole, L. B.; Claiborne, A. Analysis of the Kinetic Mechanism of Enterococcal NADH Peroxidase Reveals Catalytic Roles for NADH Complexes with both Oxidized and Two-Electron-Reduced Enzyme Forms. Biochemistry 1995, 34, 14114-14124.

(25) (a) Murataliev, M. B.; Klein, M.; Fulco, A.; Feyereisen, R Functional Interactions in Cytochrome P450BM3: Flavin Semiquinone Intermediates, Role of $\mathrm{NADP}(\mathrm{H})$, and Mechanism of Electron Transfer by the Flavoprotein Domain. Biochemistry 1997, 36, 8401-8412. (b) Birrell, J. A.; Yakovlev, G.; Hirst, J. Reactions of the Flavin Mononucleotide in Complex I: A Combined Mechanism Describes NADH Oxidation Coupled to the Reduction of $\mathrm{APAD}^{+}$, Ferricyanide, or Molecular Oxygen. Biochemistry 2009, 48, 1200512013. (c) Fukuzumi, S.; Inada, O.; Suenobu, T. Mechanisms of Electron-Transfer Oxidation of NADH Analogues and Chemiluminescence. Detection of the Keto and Enol Radical Cations. J. Am. Chem. Soc. 2003, 125, 4808-4816.

(26) (a) Yano, T.; Rahimian, M.; Aneja, K. K.; Schechter, N. M.; Rubin, H.; Scott, C. P. Mycobacterium Tuberculosis Type II NADHMenaquinone Oxidoreductase Catalyzes Electron Transfer through a 
Two-Site Ping-Pong Mechanism and Has Two Quinone-Binding Sites. Biochemistry 2014, 53, 1179-1190. (b) Afanasyeva, M. S.; Taraban, M. B.; Purtov, P. A.; Leshina, T. V.; Grissom, C. B. Magnetic Spin Effects in Enzymatic Reactions: Radical Oxidation of NADH by Horseradish Peroxidase. J. Am. Chem. Soc. 2006, 128, 8651-8658. (c) Xie, T.; Wu, Z.; Gu, J.; Guo, R.; Yan, X.; Duan, H.; Liu, X.; Liu, W.; Liang, L.; Wan, H.; Luo, Y.; Tang, D.; Shi, H.; Hu, J. The Global Motion Affecting Electron Transfer in Plasmodium Falciparum type II NADH Dehydrogenases: a Novel Non-competitive Mechanism for Quinoline Ketone Derivative Inhibitors. Phys. Chem. Chem. Phys. 2019, 21, 18105-18118.

(27) (a) Matsumura, H.; Matsuda, K.; Nakamura, N.; Ohtaki, A.; Yoshida, H.; Kamitori, S.; Yohda, M.; Ohno, H. Monooxygenation by a Thermophilic Cytochrome P450via Direct Electron Donation from NADH. Metallomics 2011, 3, 389-395. (b) Matsuo, T.; Mayer, J. M. Oxidations of NADH Analogues by cis- $\left[\mathrm{Ru}^{\mathrm{IV}}(\text { bpy })_{2}(\text { py })(\mathrm{O})\right]^{2+}$ Occur by Hydrogen-Atom Transfer Rather than by Hydride Transfer. Inorg. Chem. 2005, 44, 2150-2158.

(28) (a) Zhu, X.-Q.; Yang, Y.; Zhang, M.; Cheng, J.-P. First Estimation of $\mathrm{C}_{4}-\mathrm{H}$ Bond Dissociation Energies of NADH and Its Radical Cation in Aqueous Solution. J. Am. Chem. Soc. 2003, 125, 15298-15299. (b) Olek, R. A.; Ziolkowski, W.; Kaczor, J. J.; Greci, L.; Popinigis, J.; Antosiewicz, J. Antioxidant Activity of NADH and its Analogue-An in Vitro study. J. Biochem. Mol. Biol. 2004, 37, 416-421. (29) Warren, J. J.; Tronic, T. A.; Mayer, J. M. Thermochemistry of Proton-Coupled Electron Transfer Reagents and its Implications. Chem. Rev. 2010, 110, 6961-7001.

(30) (a) Litwinienko, G.; Ingold, K. U. Abnormal Solvent Effects on Hydrogen Atom Abstraction. 2. Resolution of the Curcumin Antioxidant Controversy. The Role of Sequential Proton Loss Electron Transfer. J. Org. Chem. 2004, 69, 5888-5896. (b) Litwinienko, G.; Ingold, K. U. Abnormal Solvent Effects on Hydrogen Atom Abstractions. 1. The Reactions of Phenols with 2,2-Diphenyl-1picrylhydrazyl $\left(\mathrm{dpph}^{\bullet}\right)$ in Alcohols. J. Org. Chem. 2003, 68, 34333438.

(31) (a) Bordwell, F. G.; Cheng, J.-P.; Harrelson, J. A. Homolytic Bond Dissociation Energies in Solution from Equilibrium Acidity and Electrochemical Data. J. Am. Chem. Soc. 1988, 110, 1229-1231. (b) Zhang, X.-M.; Bruno, J. W.; Enyinnaya, E. Hydride Affinities of Arylcarbenium Ions and Iminium Ions in Dimethyl Sulfoxide and Acetonitrile. J. Org. Chem. 1998, 63, 4671-4678. (c) Zhu, X.-Q.; Zhou, J.; Wang, C.-H.; Li, X.-T.; Jing, S. Actual Structure, Thermodynamic Driving Force, and Mechanism of BenzofuranoneTypical Compounds as Antioxidants in Solution. J. Phys. Chem. B 2011, 115, 3588-3603.

(32) Fu, Y.-H.; Shen, G.-B.; Li, Y.; Yuan, L.; Li, J.-L.; Li, L.; Fu, A.K.; Chen, J.; Chen, B.-L.; Zhu, L.; Zhu, X.-Q. Realization of Quantitative Estimation for Reaction Rate Constants Using only One Physical Parameter for Each Reactant. ChemistrySelect 2017, 2, 904925.

(33) (a) Zhu, X.-Q.; Li, X.-T.; Han, S.-H.; Mei, L.-R. Conversion and Origin of Normal and Abnormal Temperature Dependences of Kinetic Isotope Effect in Hydride Transfer Reactions. J. Org. Chem. 2012, 77, 4774-4783. (b) Shen, G.-B.; Xia, K.; Li, X.-T.; Li, J.-L.; Fu, Y.-H.; Yuan, L.; Zhu, X.-Q. Prediction of Kinetic Isotope Effects for Various Hydride Transfer Reactions Using a New Kinetic Model. J. Phys. Chem. A 2016, 120, 1779-1799.

(34) (a) Zhu, X.-Q.; Deng, F.-H.; Yang, J.-D.; Li, X.-T.; Chen, Q.; Lei, N.-P.; Meng, F.-K.; Zhao, X.-P.; Han, S.-H.; Hao, E.-J.; Mu, Y.-Y. A Classical but New Kinetic Equation for Hydride Transfer Reactions. Org. Biomol. Chem. 2013, 11, 6071-6089. (b) Li, Y.; Zhu, X.-Q. Theoretical Predictiong of Activation Free Energies of Various Hydride Self-Exchange Reactions in Acetonitrile at 298 K. ACS Omega 2018, 3, 872-885. 